\title{
Icelandic Coastal Sea Surface Temperature Records Constructed: Putting the Pulse on Air-Sea-Climate Interactions in the Northern North Atlantic. Part I: Comparison with HadISST1 Open-Ocean Surface Temperatures and Preliminary Analysis of Long-Term Patterns and Anomalies of SSTs around Iceland
}

\author{
EDWARD HANNA \\ Department of Geography, University of Sheffield, Sheffield, United Kingdom \\ TRAUSTI JÓNSSON \\ Icelandic Meteorological Office, Reykjavík, Iceland \\ Jon ÓlafsSOn AND Hedinn VALDimarsson \\ Marine Research Institute, Reykjavík, Iceland
}

(Manuscript received 21 October 2005, in final form 14 February 2006)

\begin{abstract}
A new comprehensive record of long-term Icelandic sea surface temperature measurements, which have been updated and filled in with reference to air temperature records, is presented. The new SST series reveal important features of the variability of climate in Iceland and the northern North Atlantic. This study documents site histories and possible resulting inconsistencies and biases, for example, changes in observing sites and instruments.

A new 119-yr continuous time series for north Iceland SST is presented, which should prove particularly useful for investigating air-sea ice interactions around northern Iceland. As this is the only part of the country to be regularly engulfed by winter and/or spring sea ice, it is therefore highly sensitive to climatic change. The coastal series correlate well overall with independent Hadley Centre Sea Ice and SST dataset version 1 (HadISST1) series from the adjacent open ocean (mean $r=0.59$ ), although correlations are generally higher in summer than winter and for south and east Iceland compared with the west and north. The seasonal temperature range is generally twice as large at the coastal sites because of differential effects of radiation, melting, mixing, and advection of warmer or colder air or water masses, as well as spatial resolution differences and smoothing in HadISST1.

The long-term climatological averages and graphs for the 10 SST stations and/or their composites reveal decadal variations and trends that are generally similar to Icelandic air temperature records: a cold latenineteenth-century, rapid warming around the 1920s, an overall warm peak circa 1940, cooling until an "icy" period circa 1970, followed by warming. Regional differences between sites include relatively greater (lesser) long-term variations for the eastern and southern (western and northern) Icelandic coasts, suggesting greater variability and influence of ocean current advection in the southeast. Moreover, Vestmannaeyjar SST data reveal that the late-nineteenth-century cold period in the ocean was not confined to the cold currents off north and east Iceland but also affected the south coast markedly. The Stykkishólmur, Iceland, SST record is relatively noisy and shows very little decadal variation, which may largely be due to fjord ice in cold winters suppressing low temperatures. It is anticipated that researchers may find these Icelandic SST series of practical use as a historic measure of air-sea-climate interactions around Iceland.
\end{abstract}

\section{Introduction}

Following our comprehensive analysis of recent changes in Icelandic climate (Hanna et al. 2004), here

Corresponding author address: Edward Hanna, Department of Geography, University of Sheffield, Winter Street, Sheffield, S10 2TN, United Kingdom.

E-mail: ehanna@sheffield.ac.uk we present a long-overdue update of Icelandic sea surface temperature (SST) records (Part I) and in a subsequent paper compare them with coastal airtemperature series (Hanna et al. 2006, unpublished manuscript, hereafter Part II). Statistical and graphical comparisons of the two temperature sets enable us to assess long-term (monthly-multidecadal) air-sea interaction in this climatically crucial area of the North Atlantic. 


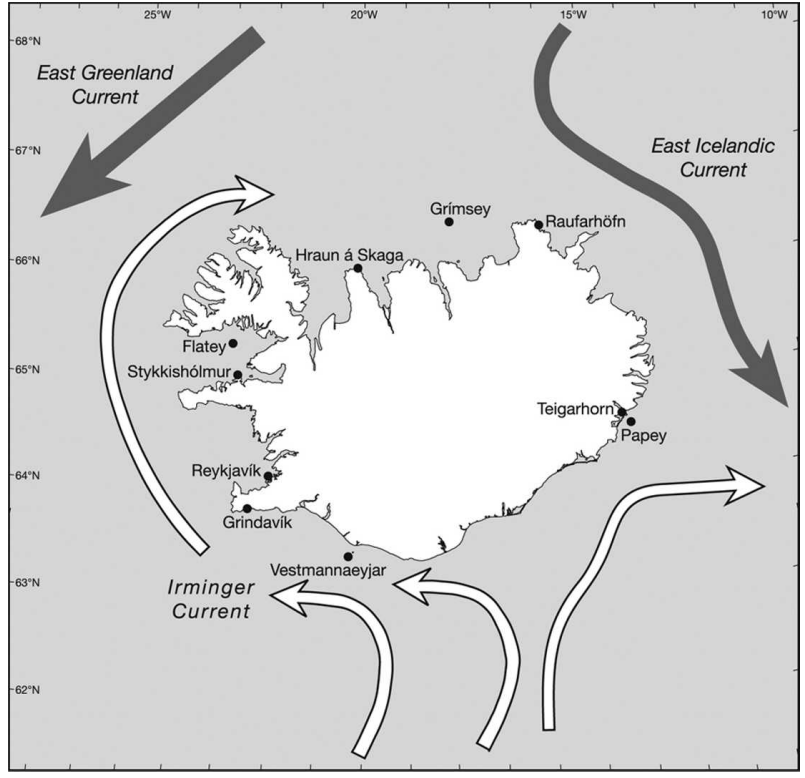

FIG. 1. Icelandic stations map with main ocean currents depicted

The few previous papers relating to this subject include pioneering works by Stefánsson (1954), Stefánsson (1962), and Stefánsson and Gudmundsson (1969), which report early series of temperature variations and hydrographic conditions mainly off northern Iceland. More recently, Jónsson (1999) presents an analysis of seven 1987-96 coastal SST series compiled by the Icelandic Marine Research Institute (MRI). The original primary purpose of these additional measurements was mariculture; however, they were later deemed highly suitable for long-term climatic monitoring (Jónsson 1999). Temperature deviations of all seven stations from the calender month means suggest coherence of large-scale, long-term variations, but, as there are no MRI data from around the south coast of Iceland (which might reveal some differences linked with varying influx of Atlantic water), the study was insufficient to demonstrate this for Icelandic waters as a whole (Jónsson 1999). On the other hand, Ólafsson (1999) points out that interannual hydrographic variability is much greater north of Iceland than off the south due to constant interaction and changes between the Atlantic and Arctic currents.

There is considerable information on SST to be found in the database and archives of the Icelandic Meteorological Office (IMO; Jónsson 2004). However, during the last $30 \mathrm{yr}$ or so the measurements have been getting sparser, and some of the longest series are badly affected. We therefore fill in some recent gaps using updated SST data from the MRI. Data are generally updated, where available, to late 2004. Figure 1 shows all the SST station locations, whose coordinates and observation periods are given in Table 1, and the main ocean currents influencing Iceland. A recent false color infrared satellite picture depicts typical summer SST variations around Iceland (Fig. 2).

Information on observing methods at each station is very sparse, and it is likely that it has changed somewhat at each station; we include a translation of the present set of IMO (1981) observation rules in appendix A. These are essentially almost identical to the 1880 rules of the Danish Meteorological Institute (DMI), which was measuring SST in Iceland from 1872 to 1920 (see next section). However, the observation frequency has decreased to only 8-15 times per month during the past few decades. MRI observation practice at the automatic SST stations is presented in appendix B and is rather similar.

The raw station records have many gaps, and we have filled some of these using statistical relations between monthly sea and air temperatures at the stations in question.

The environment has changed in some cases, but at a few sites such changes are only minor. It must be emphasized that the measurements are made from land and show the temperature at a beach, below cliffs or even inside harbors. The tidal zone configuration or area flooded by high tide can strongly influence coastal SST measurements, as there is, for example, a 4-m tidal range at Reykjavík. Some random influences by solar or longwave radiation, precipitation, snowmelt, or runoff are to be expected. Also, localized shore ice may occasionally form at the beach in winter, while not offshore in the Irminger Current, which might reduce the winter shore temperature. In a few cases the measurements were disturbed by sea ice, mainly during the 1880 s.

There is a seasonal cycle of mixing between a shallow (thermocline) layer and the deeper water (Fig. 3). At the coast this mixing takes place in autumn, when the warm thermocline waters of the summer cool rather rapidly, both by radiation and by wind-induced mixing. In late winter there is an inverse thermocline at the coast and radiative cooling (which should induce more mixing) is offset by flux of meltwater from land, the meltwater dominating in spring and reinforcing the radiation-induced thermocline of summer. There are some interannual differences of the winter situation because in some winters the runoff from land is very small due to either very dry conditions and/or no melt (because of cold weather; Stefánsson 1962, p. 179).

\section{Icelandic SST records}

Icelandic SST measurements were first coordinated by the Danish Meteorological Institute in the early 
TABLE 1. Locations of Icelandic SST stations used in this study.

\begin{tabular}{llll}
\hline \hline \multicolumn{1}{c}{ Name } & Lat $\left({ }^{\circ} \mathrm{N}\right)$ & Lon $\left({ }^{\circ} \mathrm{W}\right)$ & \multicolumn{1}{c}{ Period(s) of observations* } \\
\hline Reykjavík & $64^{\circ} 07^{\prime}$ & $21^{\circ} 54^{\prime}$ & $1832-54,1920-80,1985-2001$, and 2004 \\
Stykkishólmur & $65^{\circ} 04^{\prime}$ & $22^{\circ} 43^{\prime}$ & $1866-1985$ \\
Flatey & $65^{\circ} 22^{\prime}$ & $22^{\circ} 55^{\prime}$ & $1990-2004$ \\
Hraun á Skaga & $66^{\circ} 06.762^{\prime}$ & $20^{\circ} 06.622^{\prime}$ & $1955-2004$ \\
Grímsey & $66^{\circ} 32^{\prime}$ & $18^{\circ} 01^{\prime}$ & $1874-1958,1960-75$, and 1987-2004 \\
Raufarhöfn & $66^{\circ} 27^{\prime}$ & $15^{\circ} 57^{\prime}$ & $1922-2004$ \\
Teigarhorn & $64^{\circ} 40.547^{\prime}$ & $14^{\circ} 20.715^{\prime}$ & $1873-1991,1993$, and 1996-2002 \\
Papey & $64^{\circ} 35^{\prime}$ & $14^{\circ} 10^{\prime}$ & $1874-1949$ \\
Vestmannaeyjar & $63^{\circ} 24^{\prime}$ & $20^{\circ} 17^{\prime}$ & $1877-1964$ and 1999-2003 \\
Grindavík & $63^{\circ} 50^{\prime}$ & $22^{\circ} 26^{\prime}$ & $1922-60$ and 1969-2004 \\
\hline
\end{tabular}

* Not necessarily complete monthly data for each year.

1870s. However, prior to this, J. Porsteinsson, a medical doctor in Reykjavík, measured sea surface temperatures, first at his residence at Nes (very close to Reykjavík) from March 1832 to 17 October 1833 and then in Reykjavík to the end of February 1854. It is probable that the measurements in Reykjavík were made at the beach below his residence at Ránargata. This beach disappeared a long time ago as a permanent harbor was constructed in Reykjavík. Temperature readings are given only to the nearest degree and a few months are missing from the measurements. After 1854 SST measurements did not commence again in Reykjavík until the establishment of the IMO in 1920. From 1920 to the 1960s measurements were made very regularly; thereafter they were more irregular. Until 1958 measurements were made by the harbor, close to the former Porsteinsson site, but thereafter at Grótta, very close to the Nes site of Porsteinsson. Readings from February 1969 onward were taken by the MRI, once again in the harbor. There are, unfortunately, large chunks of missing data from April 1980 to January 1985 and January 2002 to May 2004 inclusive.

The Stykkishólmur SST record begins in October 1866 and continues more or less uninterrupted until 1985. Measurements were recorded as being made in water "6 feet deep" ( $2 \mathrm{~m})$ from 1866 until at least 1873 , which is considerably greater than the standard depth $(0.25-0.5 \mathrm{~m})$ generally used. There are a few gaps in the series: one during the last part of 1892 and another during the general observation gap at the station from August to December 1919. MRI measurements from nearby Flatey, 1990-2004, are used to extend the Stykkishólmur SST series.

SST measurements started on Grímsey in May 1874, at Djúpivogur in November 1872 (the station was relocated $\sim 5 \mathrm{~km}$ to nearby Teigarhorn in 1881), on Papey in 1873, and at Vestmannaeyjar in 1877. The Teigarhorn measurements continue to this day, but there are many large gaps during the last $20 \mathrm{yr}$. The Grímsey measurements continued to 1958 , with later measurements made by the MRI; there are many gaps after 1923 in addition to the general observation gap and subsequent change of observer in 1895-56, and a prolonged break in measurements from 1975-87. The Grímsey sea thermometer broke in 1880, which might explain the seemingly high values earlier. Papey continued to 1949 with almost no gaps. There are only a few gaps in Vestmannaeyjar until the observations stopped in 1964. There was a major relocation of the station in October 1921, but it is unknown whether this had any influence on the SST measurements, and there is no obvious inhomogeneity at that point.

The IMO increased the number of sea surface observation stations after 1920. SST measurements started at Hraun on Skagi in 1955 and have continued since. This is one of the very few continuous series during the last 25 yr along with Raufarhöfn and Grindavík: only a few months are missing. SST measurements were started at Raufarhöfn in 1922 and have continued since; there are disturbing gaps in the 1940s, but otherwise the series is fairly complete with only a few months' gaps. Here we combine the Hraun and Raufarhöfn series with the one from Grímsey, thus producing a novel complete 119-yr series representing surface oceanographic conditons off the north Icelandic coast. The station in Grindavík measured SSTs from 1929 to 1960 and again from 1969 onward. There are only a few gaps in both series segments, except for large gaps in 1944 and 1947. There have been considerable changes in the harbor in Grindavík, and it is not certain that the early part of the series is comparable to the later measurements.

The IMO also has reasonably long-running (i.e., multidecadal) SST series from Sudureyri in northwestern Iceland (north of Stykkisholmur), in 1921-89, and Thorvaldstadir in the northeast (1952-95). However, as these series end at least a decade before the present 


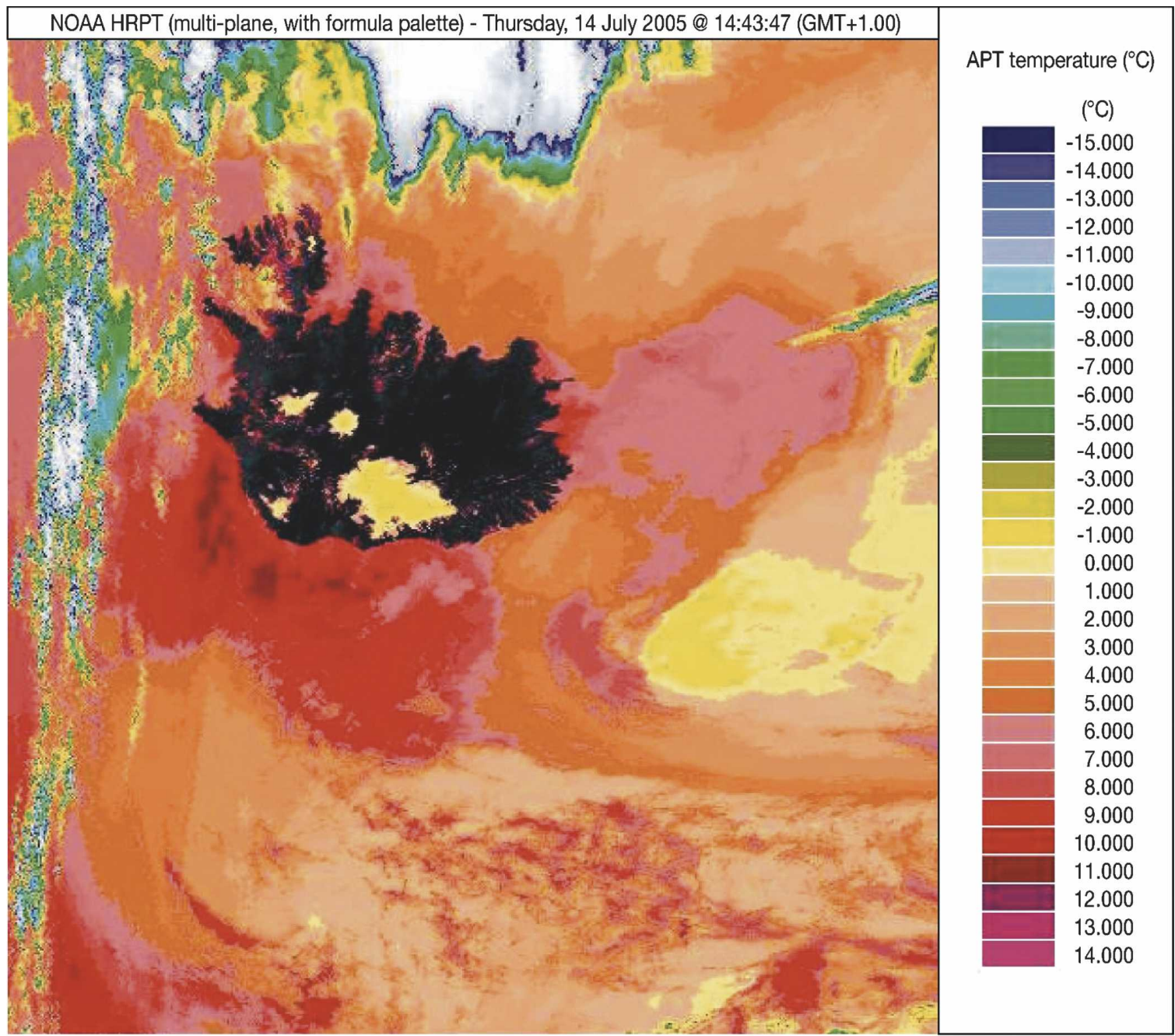

Satellite: NOAA 16

Raw (unprojected) format. Standard channel data, enhanced calibration.

Formula palette was generated using the "APT temperature $\left({ }^{\circ} \mathrm{C}\right)$ " formula: result $=$ calib(blue)

Plymouth

FIG. 2. False color infrared satellite picture of Iceland and its surrounds for typical summer conditions (14 Jul 2005). This image depicts relatively warm $\left(\sim 9^{\circ} \mathrm{C}\right)$ SSTs in Atlantic waters south of Iceland and close by parts of the northern shores, and relatively colder $\left(\sim 4^{\circ}-5^{\circ} \mathrm{C}\right)$ polar waters off Grímsey and farther north. Image courtesy of L. Wood, University of Plymouth.

time and there are no available additional in situ data near those locations to extend them, we do not consider them any further here.

\section{SST record infilling}

Monthly SSTs are mainly based on at least eight daily measurements made during the respective month, although some monthly values are based on four to eight nonconsectutive daily SST measurements. Monthly air temperature values were used to fill in many gaps in the SST records as follows.

(i) If the air temperature was not far from the mean, the filling was done by setting the air temperatureSST difference equal to the mean difference between the air and SST during the same month of the two years preceding and the two years following the gap. The SST was calculated from this mean difference and the air temperature. If one or more of the two preceding or following months were also miss- 


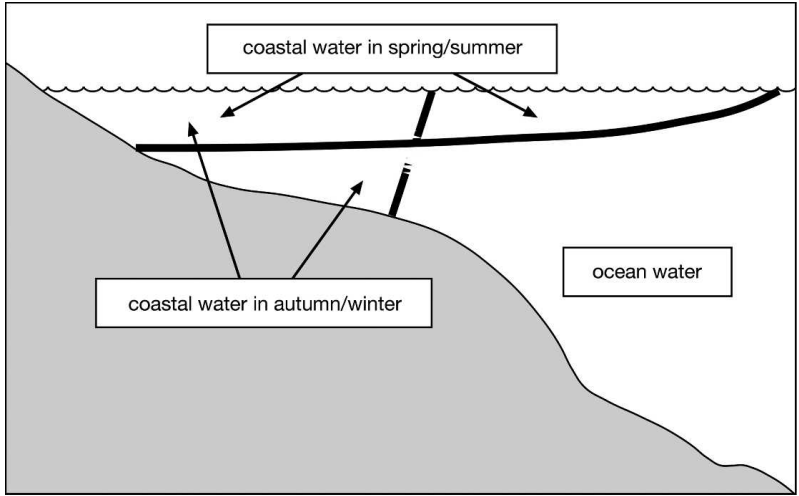

FIG. 3. Typical winter and summer boundaries of coastal and oceanic waters at the coast of Iceland. Modified from Fig. 125 of Stefánsson (1962, p. 176).

ing, three months were used on one side and one on the other-or, in a very few cases, four on one side and none on the other. In most cases the filled SST is within a standard deviation of the mean of the four months used for the infilling.

(ii) If air temperature is far from the mean, the air temperature-SST difference is less likely to be close to typical averages but is instead considered to be similar to the air temperature-SST difference for another month of the same name with air temperature similar to the month with the gap.

Method (i) is the main gap-filling rule, used except when the filling would break a record in the series; artificial absolute records are to be sensibly avoided or rather double checked with method (ii) - if there is still a record, then it might be real. Very few type-(ii) fillings were made: none at Grindavík; May 1958 only at Vestmannaeyjar; none at Papey; March 1962 only at Teigarhorn; March 1951 only at Raufarhöfn; and March 1939, February and July 1943, March 1951 and June 1952 at Grímsey. We believe our method disturbs the longterm (decadal) variations of SST and T(air)-SST series as little as possible, even though some individual monthly infillings might be suboptimal. We checked the procedure by deleting real data and substituting test data, with good agreement in most cases. Other stations were not used for infilling, which avoids the possibility of contamination between stations.

\section{Validation and comparison of Icelandic coastal SST with HadISST1}

We used the recent Hadley Centre Sea Ice and SST dataset version 1 (HadISST1; Rayner et al. 2003) to help validate our Icelandic coastal SST series and to compare coastal SST at particular (or nearby) points with those representative of much larger areas of adjacent open ocean. HadISST1 data are a globally complete monthly series of $1^{\circ}$ latitude-longitude gridded SST (and sea ice) data from 1871 to the present time. They are based on bias-adjusted data from ships, buoys, and 1982 National Oceanic and Atmospheric Administration (NOAA) Advanced Very High Resolution Radiometer (AVHRR) infrared satellite radiometers (nighttime data only used for latter), with statistical (reduced space optimal interpolation) inference over data-sparse regions (Rayner et al. 2003). In situ observations were taken from the Met Office Marine Data Bank and the Comprehensive Ocean-Atmosphere Data Set (COADS). There are likely to be plenty of ships having called into or passed near Iceland, albeit with only some of them measuring SST: hence this part of the dataset is probably quite reliable.

HadISST1 does not include coastal SST observations as these are deemed to possibly have local biases and are therefore not properly representative of conditions in the nearby open ocean. Rayner et al. (2003) used statistical relationships between SST and sea ice concentration to estimate SST in areas partly covered by sea ice: these occasionally include areas just north of Iceland. HadISST1 was generated with the specific purpose of minimizing random errors, sampling noise, and systematic biases, to preseve climatic signals at the global, ocean, and subregional $(\sim 500 \mathrm{~km})$ scales (Rayner et al. 2003). However, it does not resolve very localized SST features, such as meanderings of the Gulf Stream, which is an important consideration when comparing HadISST1 data with spot coastal measurements.

The fact that HadISST1 data are entirely independent makes them particularly useful for comparison with the Icelandic SST series. We first compare mean monthly Reykjavík SST (ReykSST) and HadISST1 for a $1^{\circ}$ latitude-longitude cell centered on $64^{\circ} \mathrm{N}, 23^{\circ} \mathrm{W}$ (Fig. 4, Table 2). Note the much (2.15 times) smaller seasonal range of the HadISST1 series (Fig. 4a), which may partly be explained by suppressed variability of the HadISST1 grid cell compared with the coastal pointvalue measurements. However, mean annual temperatures are within a degree, which suggests there is not a bias due to a poorly exposed instrument.

Mean [June-August (JJA)] summer temperatures are $1.82^{\circ} \mathrm{C}$ colder for HadISST1 than Reykjavík SST, but HadISST1 is $3.33^{\circ} \mathrm{C}$ warmer than Reykjavík SST in the standard Icelandic extended winter [DecemberMarch (DJFM)] season. These differences are likely to be due to a combination of coastal, tidal, ocean current, mixing, and/or meltwater/runoff influences. As SST at the stations is measured at the shore, land influence is 
(a)

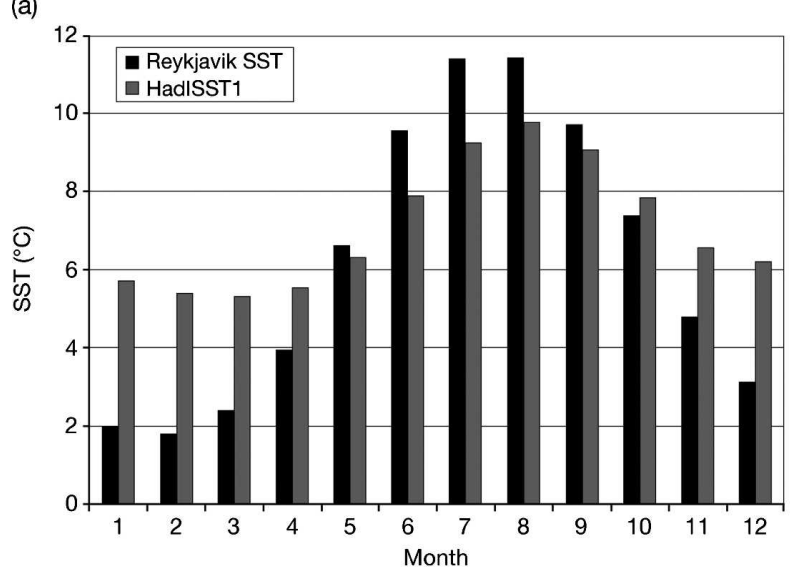

(b)

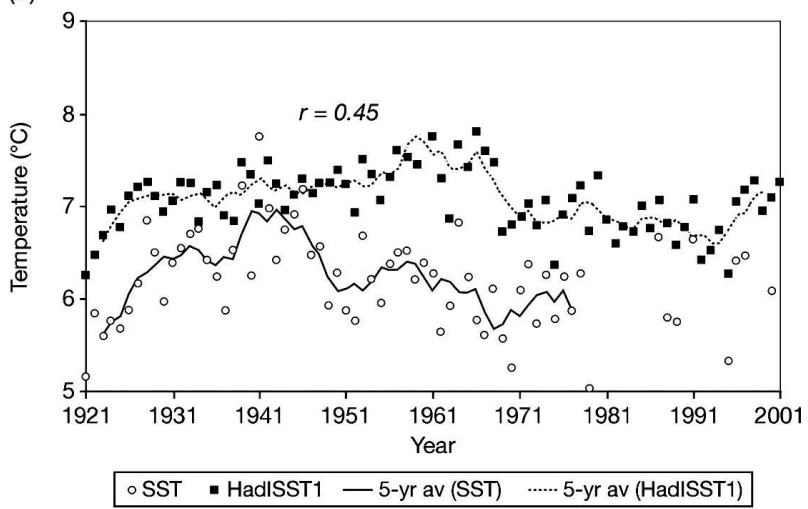

(c)

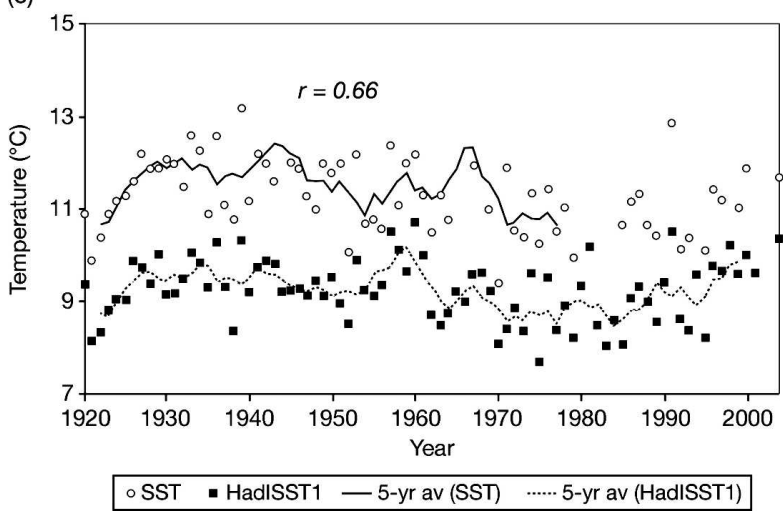

FIG. 4. (a) Comparison of mean monthly (1920-2001) Reykjavík and HadISST1 at $64^{\circ} \mathrm{N}, 23^{\circ} \mathrm{W}$. (b) Comparison of annual mean 1921-2000 Reykjavík SST and HadISST1 at $64^{\circ} \mathrm{N}, 23^{\circ} \mathrm{W}$. (c) Comparison of July 1920-2004 mean Reykjavík SST and HadISST1 at $64^{\circ} \mathrm{N}, 23^{\circ} \mathrm{W}$.

certain, not least at a station like Reykjavík that is at almost the innermost part of a bay. The HadISST1 grid square is just offshore, outside the bay and inner harbor. Reykjavík (as with most of the coastal stations) is in a very sheltered location, so we might expect its SST to have a strong link to local air temperature; therefore, a cold bias in winter and a warm bias in summer, as is evident, is very likely. However, sea temperatures can also feed back on and moderate air temperatures, but this is not enough to compensate for the above effect.

Correlation coefficients between monthly $(\sim 1920$ 2001) ReykSST and HadISST1 $(64,23)$ are strongest $(r=0.66)$ in July and summer/early autumn generally (Fig. 4c), and weaker or nonexistent during winter, but are overall significant for the annual series $(r=0.45)$ (Fig. 4b). This seasonal variation is in line with the tidal/mixing considerations outlined in section 1 and may suggest a possibly stronger coastal influence on Reykjavík SST in winter (e.g., from runoff), which effectively decorrelates coastal SST fluctuations from those of the nearby open ocean. Open water and coastal SSTs may also be decoupled in winter by stronger winds and/or different seasonal wind regimes and stronger winter cooling in the tidal zone. Similar results are obtained when comparing Stykkisholmur/Flatey SST with HadISST1 at $65^{\circ} \mathrm{N}, 20^{\circ} \mathrm{W}$ (Table 2), although correlations for most months-especially in summerare less than those obtained for Reykjavík.

Grímsey SST and HadISST1 $\left(67^{\circ} \mathrm{N}, 18^{\circ} \mathrm{W}\right)$ series are compared in Fig. 5. Winter values agree within a degree or so, but summer values are a couple of degrees higher for Grímsey SST. The HadISST1 seasonal range is still 1.71 times smaller than the Grímsey SST record, despite Grímsey being an offshore island more subject to open-ocean influences than the sites just discussed. We speculate this may possibly be because of greater incidence of ice immediately around and/or to the north of Grímsey during cold winter months, temporarily making its climate more continental. This may also possibly explain why the 1920s warming (coming out of a cold icy period) is more abrupt for Grímsey SST than for the HadISST1 grid cell. Incidentally, most sea ice at Grímsey is advected there, but not formed at the location. Very little ice surrounded Grímsey after 1920, except during the ice years of 1965-71 and 1979. The ice with its "continental" influence is usually not far off, however, and meltwaters are often advected to the immediate surroundings of the island.

East Iceland gives us the chance to compare instrumental SST at both a sheltered coastal fjord, Teigarhorn, and nearby open ocean, Papey Island, $\sim 7 \mathrm{~km}$ offshore, with HadISST1 (Figs. 6 and 7, Table 2). Both coastal and island SSTs are typically $1^{\circ}-2^{\circ} \mathrm{C}$ less than HadISST1, although this pattern reverses for Teigarhorn in summer. Teigarhorn may be even more sheltered and subject to fjord meltwaters than Reykjavík and Stykkisholmur. Mean water flow in the fjord (in general similar for most of the Icelandic fjords), where Teigarhorn is, is generally in along the northern coast 
TABLE 2. Icelandic coastal SST compared with adjacent open-ocean SST (HadISST1, as denoted by the asterisk).

\begin{tabular}{|c|c|c|c|c|c|}
\hline Station/HadISST1 pixel & Period(s) & Mean $\left({ }^{\circ} \mathrm{C}\right)$ & $\begin{array}{c}\text { Amplitude of } \\
\text { annual cycle }= \\
\text { seasonal range }\left({ }^{\circ} \mathrm{C}\right)\end{array}$ & $\begin{array}{c}\text { Standard } \\
\text { deviation of } \\
\text { annual values }\left({ }^{\circ} \mathrm{C}\right)\end{array}$ & $r$ \\
\hline Reykjavík/ $64^{\circ} \mathrm{N}, 23^{\circ} \mathrm{W}$ & 1920-2001 & $6.20^{\circ} \mathrm{C} / * 7.08$ & $9.65 / * 4.48$ & $0.51 / * 0.37$ & 0.45 \\
\hline Stykkishólmur+Flatey $/ 65^{\circ} \mathrm{N}, 24^{\circ} \mathrm{W}$ & $\begin{array}{l}1870-1985 \\
1990-2004\end{array}$ & $5.03^{\circ} \mathrm{C} / * 5.99$ & $9.96 / * 3.93$ & $0.55 / * 0.38$ & 0.43 \\
\hline Grímsey $/ 67^{\circ} \mathrm{N}, 18^{\circ} \mathrm{W}$ & 1874-2004 & $4.19^{\circ} \mathrm{C} / 3.38$ & $6.66 / * 3.90$ & $0.89 / * 0.61$ & 0.48 \\
\hline Tergarhorn $/ 65^{\circ} \mathrm{N}, 13^{\circ} \mathrm{W}$ & $1873-2002$ & $4.28^{\circ} \mathrm{C} / * 5.21$ & $7.76 / * 5.31$ & $0.87 / * 0.51$ & 0.50 \\
\hline Tergarhorn $/ 64^{\circ} \mathrm{N}, 14^{\circ} \mathrm{W}$ & $1873-2002$ & $4.28^{\circ} \mathrm{C} / * 7.58$ & $7.76 / * 4.33$ & $0.87 / * 0.43$ & 0.51 \\
\hline Papey $/ 65^{\circ} \mathrm{N}, 13^{\circ} \mathrm{W}$ & 1874-1949 & $3.68^{\circ} \mathrm{C} / * 5.11$ & $6.18 / * 5.25$ & $0.97 / * 0.36$ & 0.68 \\
\hline Papey $/ 64^{\circ} \mathrm{N}, 14^{\circ} \mathrm{W}$ & $1874-1949$ & $3.68^{\circ} \mathrm{C} / * 7.41$ & $6.18 / * 4.39$ & $0.97 / * 0.33$ & 0.64 \\
\hline Vestmannaeyjar $/ 63^{\circ} \mathrm{N}, 20^{\circ} \mathrm{W}$ & $\begin{array}{l}1877-1964 \\
1999-2003\end{array}$ & $7.58^{\circ} \mathrm{C} / * 8.74$ & $5.70 / * 4.41$ & $0.67 / * 0.33$ & 0.65 \\
\hline Grindavík $/ 63^{\circ} \mathrm{N}, 20^{\circ} \mathrm{W}$ & $\begin{array}{l}1922-60 \text { and } \\
1969-2004\end{array}$ & $7.40^{\circ} \mathrm{C} / * 8.78$ & $6.21 / * 4.39$ & $0.38 / * 0.36$ & 0.73 \\
\hline
\end{tabular}

and out along the southern coast. This can influence the temperature and salinity at Teigarhorn and make it more "land" influenced.

Papey is close to the Iceland-Faroes Front, which can

(a)

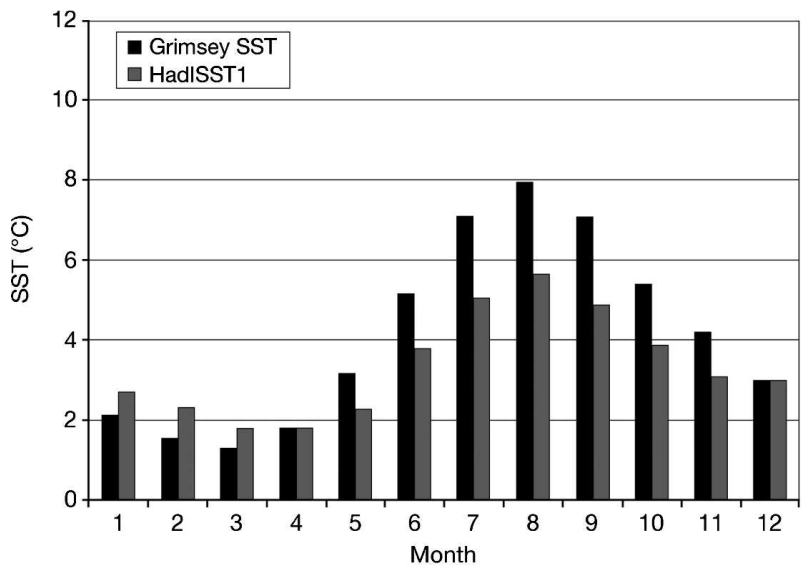

(b)

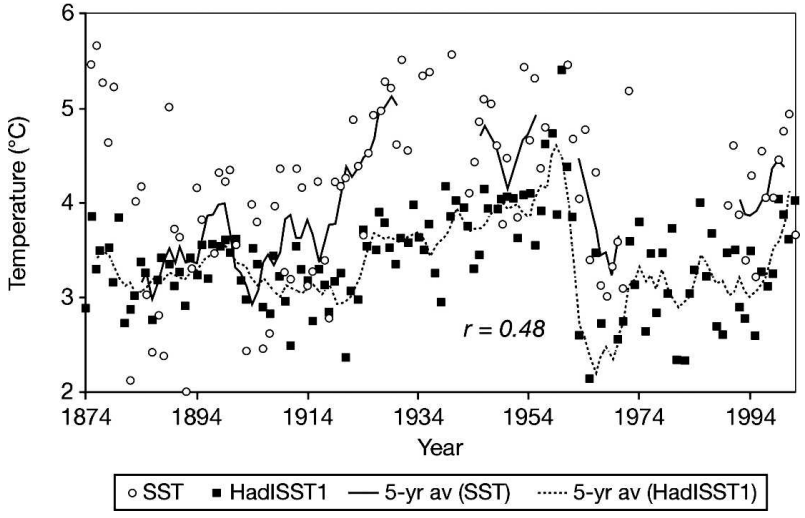

FIG. 5. (a) Comparison of mean monthly (1874-2004) Grímsey and HadISST1 at $67^{\circ} \mathrm{N}, 18^{\circ} \mathrm{W}$. (b) Comparison of annual (18752002) mean Grímsey SST and HadISST1 at $67^{\circ} \mathrm{N}, 18^{\circ} \mathrm{W}$. make the area difficult for the HadISST1, that is, the front can be smeared out in the gridding of the HadISST1. The front can be quite sharp and its meanders can move along the coast. The amplitude of the annual cycle is

(a)

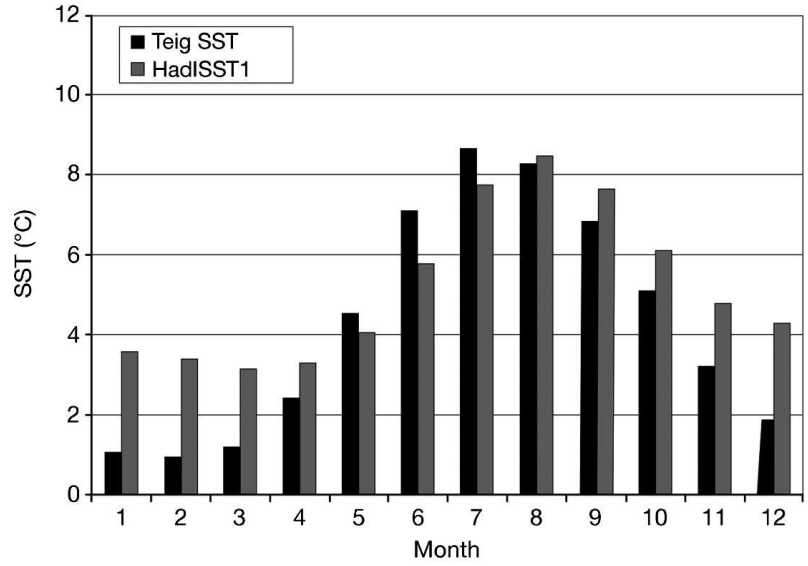

(b)

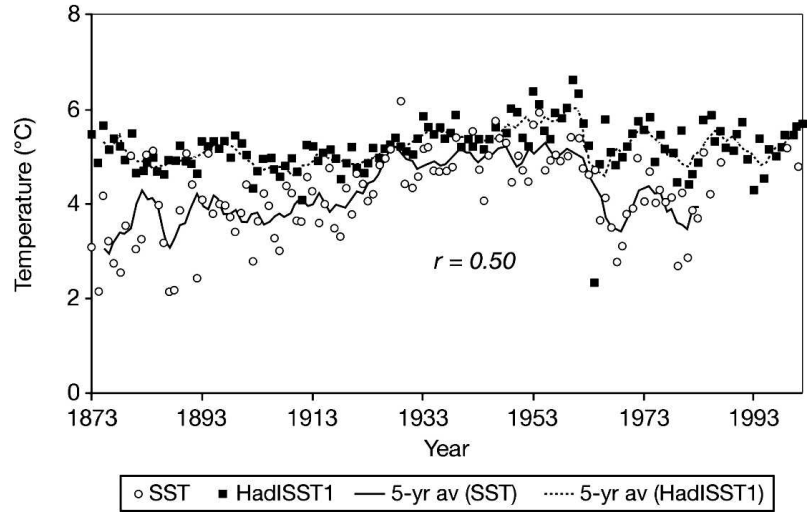

FIG. 6. (a) Comparison of mean monthly (1873-2002) Teigarhorn and HadISST1 at $65^{\circ} \mathrm{N}, 13^{\circ} \mathrm{W}$. (b) Comparison of annual mean Teigarhorn SST and HadISST1 at $65^{\circ} \mathrm{N}, 13^{\circ} \mathrm{W}$. 
(a)

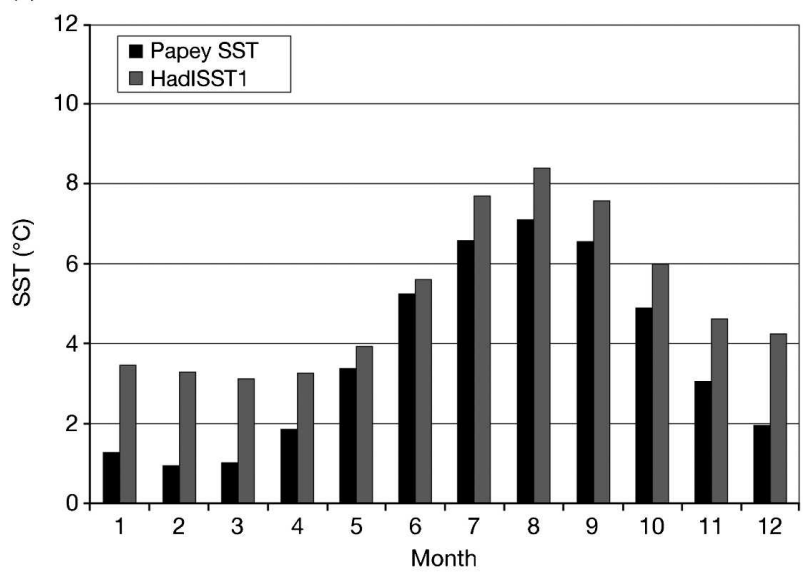

(b)

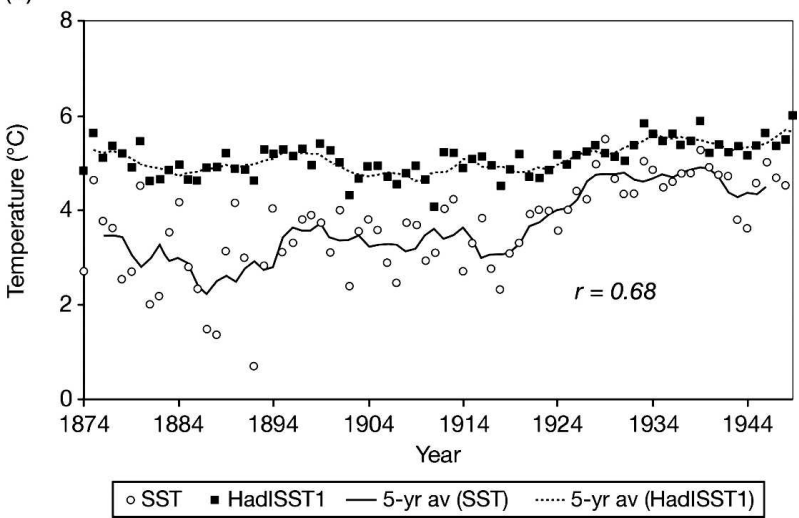

FIG. 7. (a) Comparison of mean monthly (1874-1949) Papey and HadISST1 at $65^{\circ} \mathrm{N}, 13^{\circ} \mathrm{W}$. (b) Comparison of annual mean Papey SST and HadISST1 at $65^{\circ} \mathrm{N}, 13^{\circ} \mathrm{W}$.

1.46 times (1.18 times) less in HadISST1 when comparing with Teigarhorn (Papey) SST. This result is very interesting because it indicates that the Papey measurements are reasonably capturing the seasonal variability in the open ocean as simulated by HadISST1. There is also a highly significant correlation of $r=0.68$ for annual Papey SST-versus-HadISST1, which is easily the highest correlation so far of this group of comparisons, although interannual variability is muted in the model compared with observations (relative to other stations).

Our final set of comparisons for Vestmannaeyjar and Grindavík SST versus HadISST1 shows much the same symptoms as the other series, with mainly colder coastal temperatures and greater coastal seasonal and interannual ranges than in the adjacent open ocean (Fig. 8). As already pointed out, harbor development at Grindavík may have biased its long-term record. Nevertheless, when Grindavík is combined with Vestmannaeyjar there is no obvious break apparent with excellent qualitative agreement between the two station se- (a)

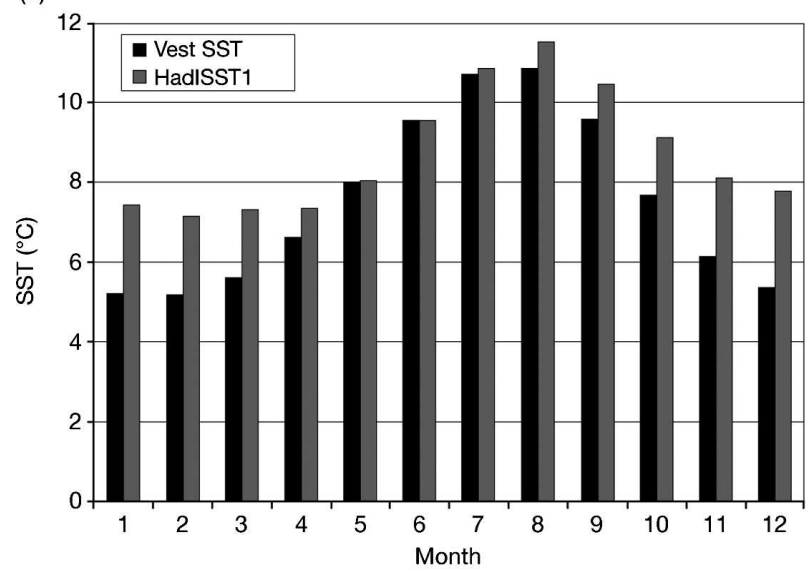

(b)

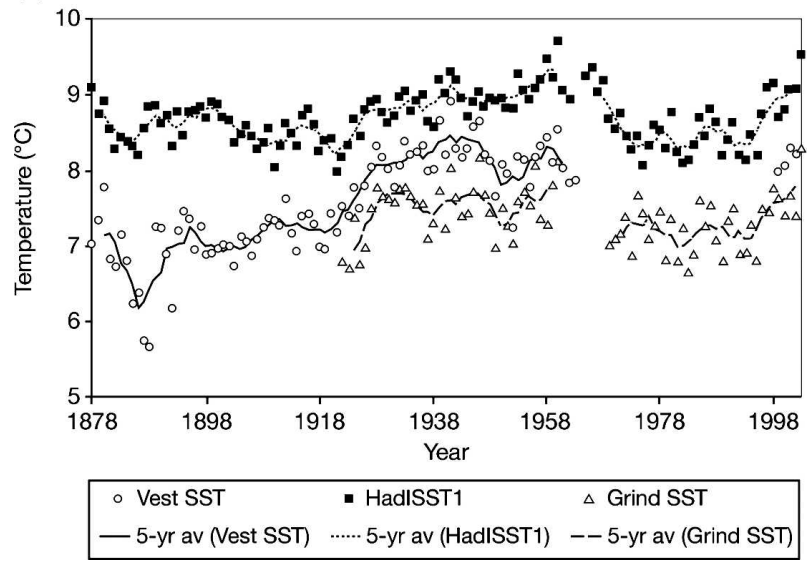

FIG. 8. (a) Comparison of mean monthly (1877-1964) Vestmannaeyjar and HadISST1 at $63^{\circ} \mathrm{N}, 20^{\circ} \mathrm{W}$. (b) Comparison of annual mean Vestmannaeyjar and Grindavík SSTs and HadISST1 at $63^{\circ} \mathrm{N}, 20^{\circ} \mathrm{W}$.

ries during the overlap period (Fig. 8b). Grindavík SST is also particularly strongly correlated with HadISST1, having the highest coefficient $(r=0.73)$ of any of the station-model comparisons, and interannual variabilities compare very well (Table 2). This may partly reflect more ship-based observations feeding into the HadISST1 dataset, tending to make it more physically realistic, for seas south of Iceland.

\section{A new north Icelandic sea surface temperature series}

We present a new 119-yr north Icelandic (NIce) SST record (1883-2001) based on regression analysis and splicing of three north coast stations: Grímsey, Hraun, and Raufarhöfn (Fig. 9; appendix C). This is enabled by the considerable coherence between the annual averages during common periods at the three stations. Ad- 
(a)

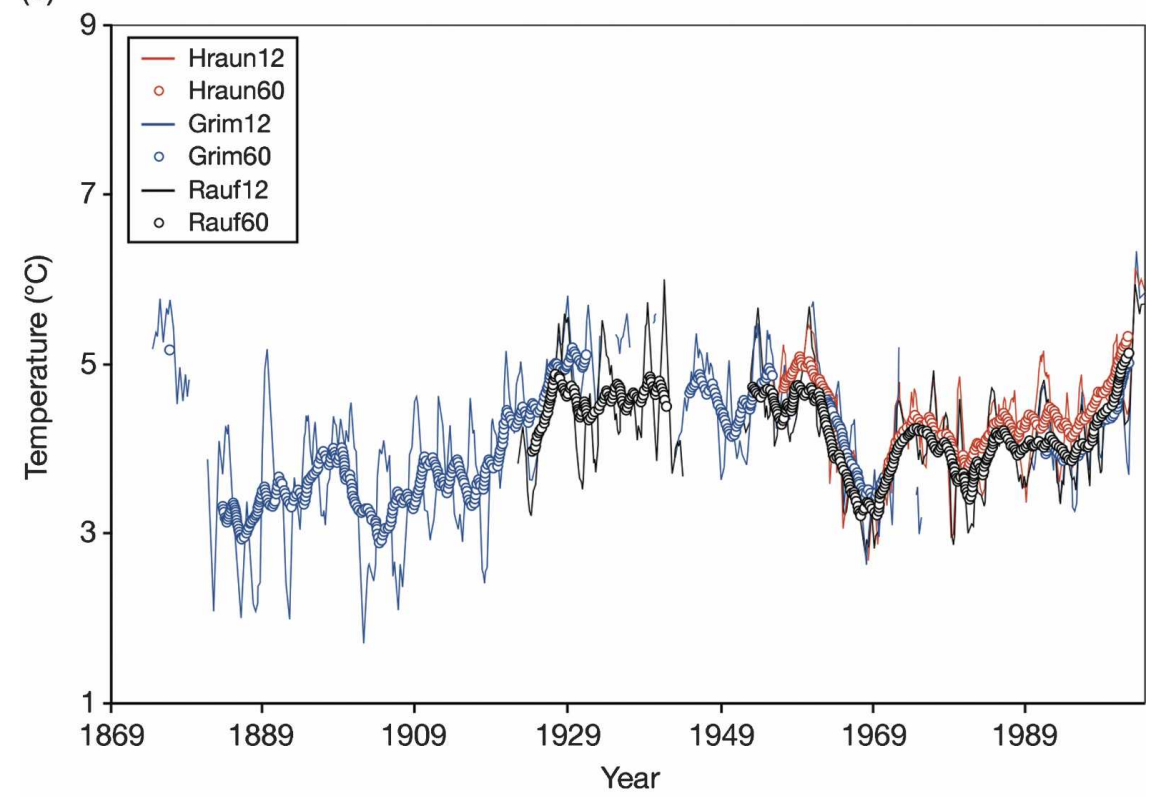

(b)

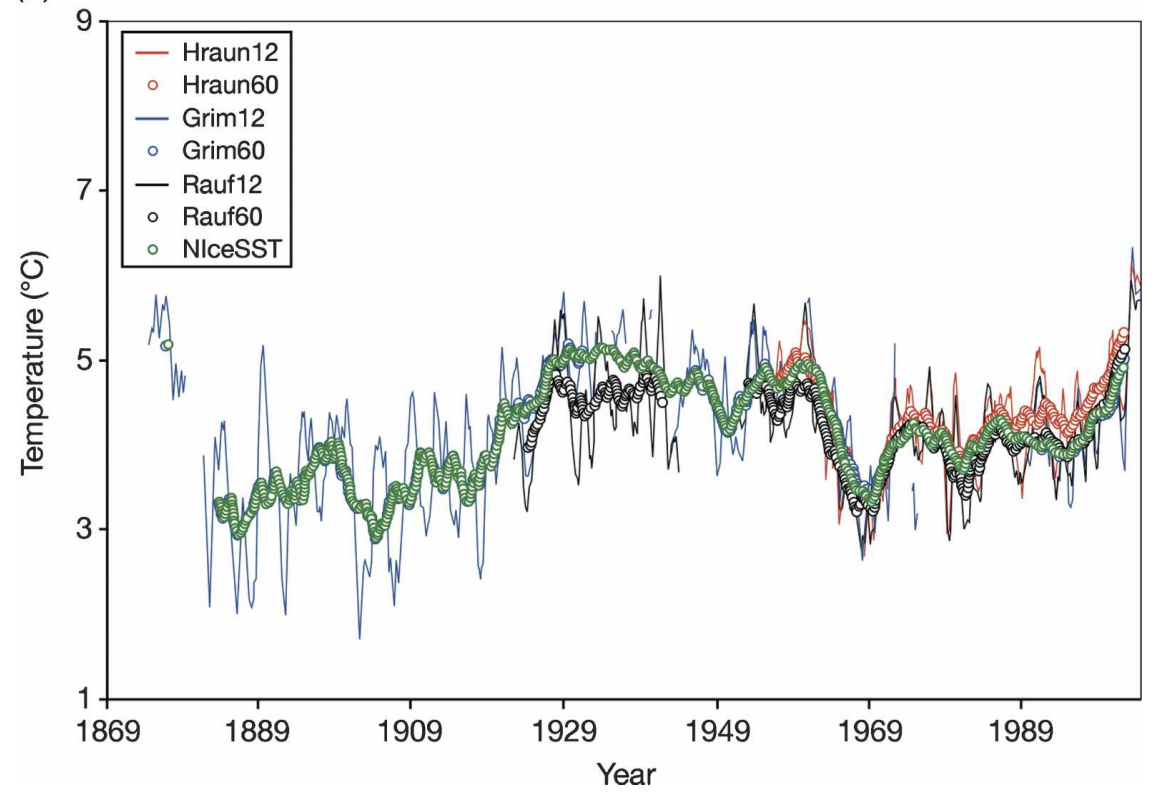

FIG. 9. (a) Running mean SSTs for Grímsey, Hraun, and Raufarhöfn. (b) A new north Icelandic SST series.

ditional support for reliability of the Grímsey SST series is given through comparison with MRI Siglunes 3 section (just west of Grímsey) SST, which is very strongly correlated (Fig. 10). However, there are insufficient section data, only about four measurements per year, to properly fill in the mid-1970s-late-1980s gap in the main Grímsey record. We consider that our NIce SST record is a good representation of coastal ocean conditions around northernmost Iceland, so it should be of general interest to those studying climatic change and air-sea ice interactions in this highly environmentally sensitive region.

\section{Interannual variations in Icelandic SST}

The filled-in SST series give a fairly good view of the variability and secular changes in coastal SST since the commencement of regular measurements in the 1870s. 


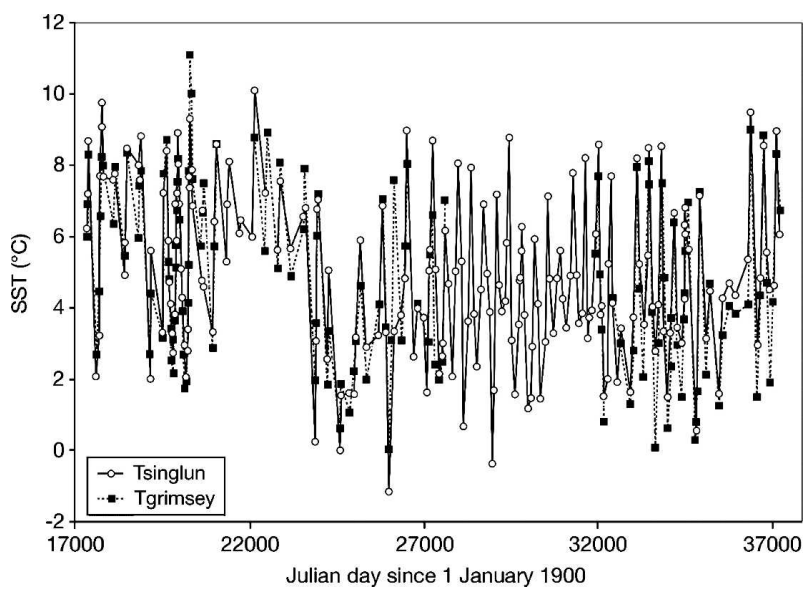

FIG. 10. Comparison of Siglunes 3 section SST with Grímsey SST data, 1947-2001.

The long-term variations follow broadly similar trends as the atmospheric temperatures, with generally similar warm and cold periods (cf. with Fig. 6 in Hanna et al. 2004). Here we concentrate on the annual series but also make occasional reference to specific months. Table 3 gives an overview of some long-term mean annual and monthly SSTs at the individual stations, and Figs. 9, 11, 12, and 13 show the annual average SST at the Icelandic stations.

\section{a. Little Ice Age (nineteenth century)}

Mid-nineteenth-century west Icelandic coastal oceanographic conditions, representative of the Little Ice Age, may be surmised from the early Reykjavík SST record. The mean Reykjavík SST during 1832-54 is $0.3^{\circ} \mathrm{C}$ lower than during 1961 to 1980 , but $0.8^{\circ} \mathrm{C}$ lower than during the warm period of 1931 to 1960 (Table 3). The difference is largest during the autumn, but the spring difference is very small and April and May are actually warmer in the earliest period. Could this indicate a shift in seasonality, for example, of ocean currents or vertical mixing of the ocean? The year 1836, a well-known cold year in the whole country, is by far the coldest of the Reykjavík series $\left(3.8^{\circ} \mathrm{C}\right)$; the two neighboring years 1835 and 1837 are the only others below $5.0^{\circ} \mathrm{C}$.

Moving several decades ahead, when the mainstream SST records start, we note that the 1870 s were cold at Teigarhorn, but relatively warm in Grímsey (off the north coast; Figs. 9 and 12). However, this Grímsey "warmth" may not be reliable due to a change of instrument. The very large interannual variability at Teigarhorn in the ninteteenth century is outstanding, with more than $4^{\circ} \mathrm{C}$ between the coldest and warmest years. In Papey Island, nearby to Teigarhorn and $\sim 7 \mathrm{~km}$ offshore, the nineteenth-century variability is also outstanding with $\sim 5^{\circ} \mathrm{C}$ difference between the coldest and warmest years (Fig. 12). Examination of the long-term SST series reveals that the cold period in the ocean was not confined to the cold currents off north and east Iceland but also affected the south coast markedly. At Vestmannaeyjar (off the south coast) 1887 and 1888 were very cold, the latter being more than $3^{\circ} \mathrm{C}$ colder than the warmest year, 1941 (Fig. 13). It seems that the west coast was least affected, and in some years (e.g., in the 1870s) relatively warm waters extended eastward off the north coast, but less off the east coast.

The question of whether entrainment of cold waters from the east (Fig. 1) suppressed the temperature off the south coast remains, and cold waters may have reached Vestmannaeyjar in 1887 and 1888. Another possibility is that the warm waters normally enveloping Vesmannaeyjar were colder in the nineteenth century than later.

\section{b. The early-mid-twentieth-century warm period (1920-65)}

The early-twentieth-century warming shows up differently at the stations, being most pronounced at $\mathrm{Pa}$ pey (Fig. 12). There is very prominent warming in the 1920 s in the NIce/Grímsey series, with a greater than $3.5^{\circ} \mathrm{C}$ difference between the coldest years in the nineteenth century and the warmest years around 1940 (Fig. 9). This was originally commented on by Stefánsson (1954) but is still obvious in the context of the whole twentieth-century record.

The 1931-60 period is the warmest one at all sites (where it is possible to calculate the means). There is a distinct SST peak about 1940 for Reykjavik and a less distinct peak around 1930 for Stykkisholmur. NIce SST also peaks in about 1930, with secondary peaks in the 1950s and again toward the present time. Teigarhorn has a flatter early-mid-twentieth-century peak, starting less abruptly and peaking in the very late 1920s and early 1950s. These differences may reflect differences in position and timing of Atlantic Ocean currents around Iceland. Five stations measure both the last decades of the nineteenth century and the 1931-60 warm period. The difference between the two periods is $1.0^{\circ} \mathrm{C}$ in Grímsey, $1.4^{\circ} \mathrm{C}$ at Teigarhorn, $1.5^{\circ} \mathrm{C}$ in Papey (only 18 out of $30 \mathrm{yr}$ during the warm period), and $1.3^{\circ} \mathrm{C}$ in Vestmannaeyjar but only $0.2^{\circ} \mathrm{C}$ at Stykkishólmur. The warm period was $0.5^{\circ} \mathrm{C}$ warmer than the following $20 \mathrm{yr}$ in Reykjavík, but the difference between these periods in Stykkishólmur is only $0.2^{\circ} \mathrm{C}(1961-85)$. At Raufarhöfn the $1931-60$ period was $0.7^{\circ} \mathrm{C}$ warmer than $1961-$ 
TABLE 3. Icelandic SST station averages for various periods.

\begin{tabular}{|c|c|c|c|c|c|c|c|c|c|c|c|c|c|}
\hline & Jan & Feb & Mar & Apr & May & Jun & Jul & Aug & Sep & Oct & Nov & Dec & $\overline{\text { Annual }}$ \\
\hline \multicolumn{14}{|l|}{ Reykjavík } \\
\hline $1832-54$ & 1.6 & 1.5 & 2.4 & 4.5 & 7.0 & 9.6 & 11.7 & 11.2 & 8.5 & 5.2 & 3.0 & 2.0 & 5.7 \\
\hline $1931-60$ & 2.3 & 1.9 & 2.6 & 4.1 & 6.8 & 9.9 & 11.8 & 11.7 & 10.2 & 7.8 & 5.4 & 3.5 & 6.5 \\
\hline $1961-80$ & 1.4 & 1.4 & 2.5 & 4.0 & 6.6 & 9.4 & 11.2 & 11.3 & 9.5 & 7.2 & 4.5 & 2.6 & 6.0 \\
\hline 1985-2001 & 2.3 & 1.9 & 1.9 & 3.6 & 6.4 & 9.2 & 11.0 & 11.5 & 9.7 & 7.4 & 5.0 & 3.3 & 6.1 \\
\hline \multicolumn{14}{|c|}{ Stykkishólmur } \\
\hline $1867-1900$ & 1.0 & 0.4 & 0.6 & 1.8 & 4.7 & 8.0 & 10.4 & 10.6 & 9.1 & 6.3 & 3.8 & 1.9 & 4.9 \\
\hline 1901-30 & 0.8 & 0.4 & 0.7 & 2.1 & 5.1 & 8.3 & 10.4 & 10.5 & 9.0 & 6.6 & 3.7 & 1.9 & 5.0 \\
\hline $1931-60$ & 1.1 & 0.7 & 1.0 & 2.4 & 5.1 & 8.1 & 10.1 & 10.5 & 9.2 & 6.7 & 4.4 & 2.4 & 5.1 \\
\hline $1961-85$ & 1.0 & 0.9 & 1.3 & 2.3 & 4.6 & 7.5 & 10.0 & 10.5 & 8.9 & 6.5 & 4.0 & 1.9 & 4.9 \\
\hline \multicolumn{14}{|c|}{ Hraun á Skaga } \\
\hline $1961-90$ & 1.0 & 0.7 & 0.7 & 1.7 & 3.6 & 6.0 & 8.2 & 8.6 & 6.9 & 5.3 & 3.5 & 2.3 & 4.0 \\
\hline 1991-2004 & 1.6 & 0.9 & 1.3 & 2.6 & 4.9 & 7.1 & 9.1 & 9.6 & 8.0 & 5.6 & 3.7 & 2.3 & 4.3 \\
\hline \multicolumn{14}{|l|}{ Grímsey } \\
\hline 1874-1900 & 2.1 & 1.2 & 0.9 & 1.5 & 2.9 & 4.6 & 6.8 & 7.8 & 7.1 & 5.5 & 4.1 & 2.8 & 3.9 \\
\hline $1901-30$ & 1.9 & 1.3 & 1.1 & 1.6 & 3.0 & 4.9 & 6.7 & 7.5 & 6.7 & 5.3 & 3.9 & 2.8 & 3.9 \\
\hline $1931-58$ & 2.4 & 2.2 & 2.0 & 2.5 & 4.0 & 6.5 & 8.2 & 8.9 & 7.7 & 6.0 & 4.7 & 3.5 & 4.9 \\
\hline $1961-75$ & 2.3 & 1.9 & 1.3 & 1.6 & 2.7 & 4.5 & 6.7 & 7.6 & 6.7 & 4.9 & 4.1 & 3.0 & 3.9 \\
\hline 1987-2003 & 2.4 & 1.4 & 1.3 & 1.9 & 3.0 & 5.1 & 6.9 & 8.0 & 7.3 & 5.2 & 4.3 & 3.2 & 4.2 \\
\hline \multicolumn{14}{|l|}{ Raufarhöfn } \\
\hline $1931-60$ & 1.4 & 0.9 & 1.0 & 2.0 & 4.6 & 7.2 & 9.1 & 9.6 & 7.6 & 5.3 & 3.9 & 2.6 & 4.6 \\
\hline 1961-90 & 1.5 & 1.1 & 0.8 & 1.2 & 2.9 & 5.3 & 7.6 & 8.3 & 7.0 & 5.3 & 3.6 & 2.3 & 3.9 \\
\hline 1991-2004 & 2.2 & 1.6 & 1.3 & 2.0 & 3.6 & 5.8 & 8.0 & 9.0 & 7.8 & 5.7 & 3.9 & 3.0 & 4.5 \\
\hline \multicolumn{14}{|l|}{ Teigarhorn } \\
\hline $1873-1900$ & 0.4 & 0.4 & 0.5 & 2.0 & 3.9 & 6.3 & 7.9 & 7.8 & 6.6 & 4.3 & 2.4 & 1.2 & 3.6 \\
\hline $1901-30$ & 1.0 & 0.8 & 1.1 & 2.2 & 4.6 & 7.5 & 9.2 & 8.1 & 6.4 & 4.9 & 2.9 & 1.7 & 4.2 \\
\hline $1931-60$ & 1.9 & 1.7 & 1.9 & 3.1 & 5.4 & 7.5 & 9.2 & 9.0 & 7.5 & 5.9 & 4.3 & 3.0 & 5.0 \\
\hline 1961-90 & 0.7 & 0.6 & 1.0 & 2.3 & 4.4 & 7.1 & 8.3 & 8.3 & 6.7 & 5.2 & 3.1 & 1.5 & 4.1 \\
\hline 1996-2002 & 1.9 & 1.8 & 1.5 & 2.5 & 4.7 & 7.0 & 9.1 & 9.2 & 8.0 & 5.9 & 4.2 & 3.1 & 4.9 \\
\hline \multicolumn{14}{|l|}{ Papey } \\
\hline $1874-1900$ & 0.6 & 0.4 & 0.3 & 1.4 & 2.9 & 4.7 & 6.0 & 6.5 & 6.1 & 4.3 & 2.6 & 1.3 & 3.1 \\
\hline $1901-30$ & 1.3 & 1.0 & 1.1 & 1.9 & 3.4 & 5.3 & 6.7 & 7.0 & 6.4 & 4.9 & 2.8 & 1.9 & 3.7 \\
\hline $1931-49$ & 2.2 & 1.7 & 1.9 & 2.6 & 4.3 & 6.1 & 7.4 & 8.2 & 7.5 & 5.9 & 4.2 & 3.2 & 4.6 \\
\hline \multicolumn{14}{|c|}{ Vestmannaeyjar } \\
\hline $1877-1900$ & 4.0 & 4.0 & 4.4 & 6.3 & 7.8 & 9.6 & 11.0 & 10.9 & 9.0 & 6.7 & 5.0 & 4.0 & 6.9 \\
\hline 1901-30 & 5.1 & 5.2 & 5.4 & 6.3 & 7.8 & 9.5 & 10.6 & 10.7 & 9.3 & 7.5 & 6.0 & 5.3 & 7.4 \\
\hline $1931-60$ & 6.0 & 6.0 & 6.5 & 7.2 & 8.5 & 9.8 & 10.9 & 11.2 & 10.2 & 8.6 & 7.1 & 6.5 & 8.2 \\
\hline 1999-2003 & 6.6 & 6.3 & 6.6 & 7.2 & 7.8 & 9.0 & 10.4 & 11.1 & 10.3 & 9.1 & 7.6 & 7.0 & 8.3 \\
\hline \multicolumn{14}{|l|}{ Gríndavík } \\
\hline 1931-60 & 5.1 & 5.0 & 5.4 & 6.1 & 7.9 & 9.7 & 10.9 & 11.0 & 9.8 & 8.0 & 6.5 & 5.6 & 7.6 \\
\hline 1969-90 & 4.6 & 4.6 & 5.1 & 5.9 & 7.7 & 9.3 & 10.4 & 10.7 & 9.4 & 7.4 & 6.0 & 5.0 & 7.2 \\
\hline 1991-2004 & 4.7 & 4.8 & 5.0 & 5.9 & 7.4 & 9.5 & 11.0 & 11.5 & 10.1 & 8.1 & 6.3 & 5.4 & 7.5 \\
\hline
\end{tabular}

$90,0.9^{\circ} \mathrm{C}$ warmer at Teigarhorn (1961-83), and $0.4^{\circ} \mathrm{C}$ warmer in Grindavík.

\section{c. The later subsequent cooling (late 1960-early 1980s)}

Stykkishólmur (Fig. 11) and Teigarhorn (Fig. 12) are the only long old series that extend uninterrupted though the cooling of the 1960s to early 1980s. In Stykkishólmur the cold years of the post-1965 period seem not to be colder than the individual cold years during the preceding warm period; the only distinction is a tendency for more cold years to cluster together. On the other hand, at Teigarhorn the "ice period," 196571, and the cold years around 1980 were distinctly colder than the coldest years during the warm period. The "ice years," 1965-71, associated with the Great Salinity Anomaly and greater incidence of sea ice off northern Iceland (Hanna et al. 2004), are very distinct in the NIce/Grímsey SST records but afterward there is 


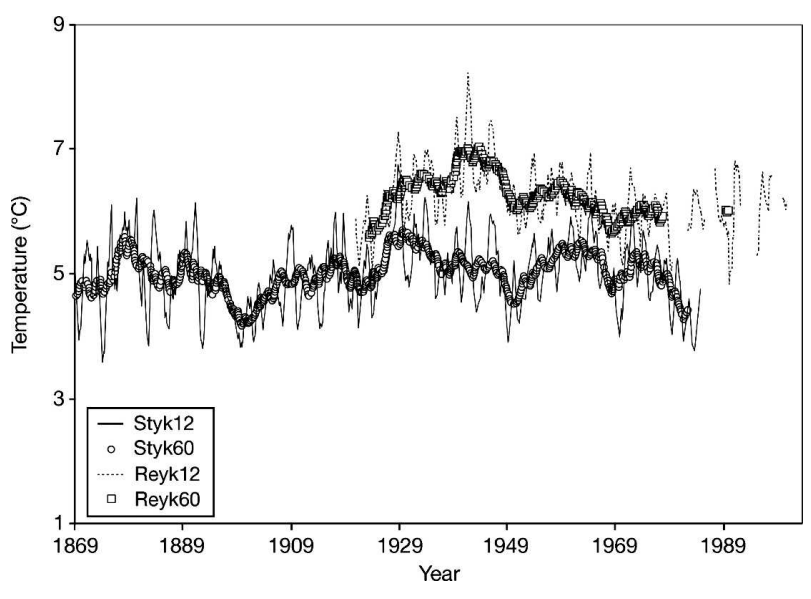

FIG. 11. Comparison of running mean SSTs for Stykkisholmur and Reykjavík.

considerable variability. Also, 1979 with a mean SST of $5.0^{\circ} \mathrm{C}$ was the coldest year in the modern (1920 onward) Reykjavík series (Fig. 11) and the fourth coldest overall (including the cold midnineteenth-century part of the record).

The year 1969, which was generally the coldest of the years around 1970, was not particularly cold in the south at Grindavík (where there were no observations from 1961-68). Here there have been large changes at the measuring site, the harbor has been significantly expanded, and nonclimatic influences are not easily ruled out. MRI section SST measurements from Selvogsbanki 2, just west of Vestmannaeyjar, may possibly be used to infer what happened at Vestmannaeyjar after measurements stopped in 1964, for example, to ascertain if the pattern is similar to Grindavík, but again (with only several measurements per year) are probably too sparse to be particularly useful for this pur-

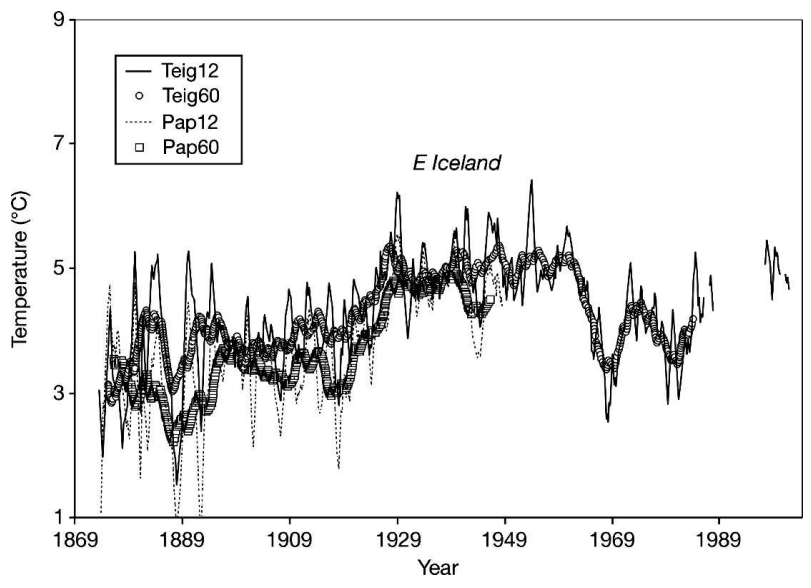

FIG. 12. Comparison of running mean SSTs for Teigarhorn and Papey.

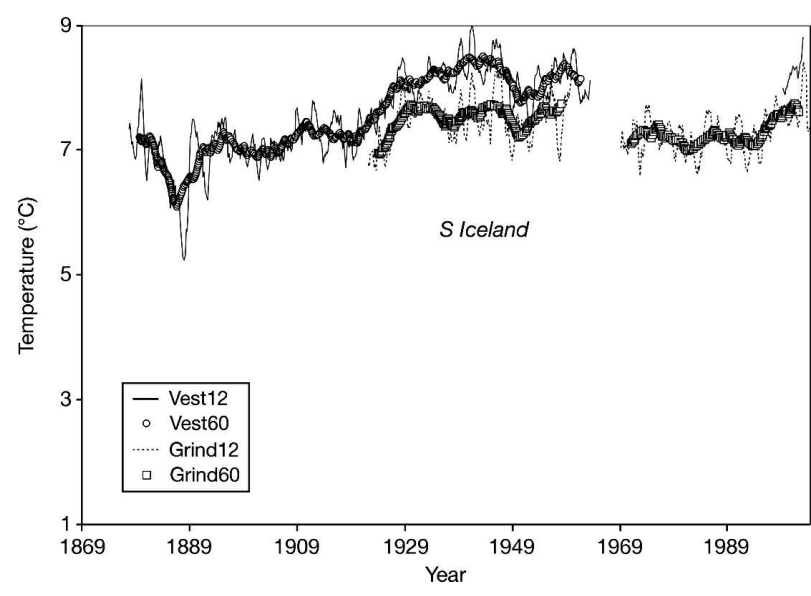

FIG. 13. Comparison of running mean SSTs for Vestmannaeyjar and Grindavík.

pose. However, as with Grímsey, the MRI sectional measurements agree very well with Vestmannaeyjar SST during the periods of overlap (Fig. 14).

\section{d. The recent strong warming since 1990}

Averages have been calculated for five stations for the post-1990 period: thus the 1991-2004 period was $0.3^{\circ} \mathrm{C}$ warmer than $1961-90$ at Hraun, $0.6^{\circ} \mathrm{C}$ warmer at Raufarhöfn, and $0.3^{\circ} \mathrm{C}$ warmer in Grindavík. At Grímsey $1987-2003$ was $0.3^{\circ} \mathrm{C}$ warmer than $1961-75$. The 1985-2001 Reykjavík SST is only $0.1^{\circ} \mathrm{C}$ warmer than 1961-80: this may suggest a lag in SSTs responding to general Icelandic warming (e.g., seen in the Reykjavík air temperature series) since about 1985 (Hanna et al. 2004). These recent mean annual values are below the respective 1931-60 means, suggesting that SSTs recently warmed but remain below the twentieth-century peak values.

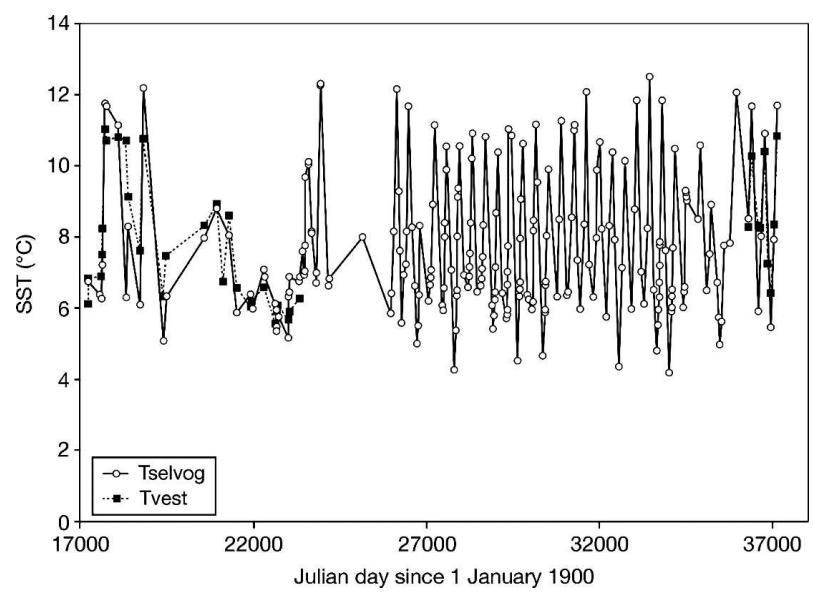

FIG. 14. Comparison of Selvogsbanki 2 section SST with Vestmannaeyjar SST data, 1947-63 and 1999-2001. 


\section{e. Special regional features of Icelandic SST changes}

The eastern and southern coasts apparently experienced thermally more distinct temporal regimes than the western and even the northern coasts. Vestmannaeyjar and Papey have the common feature that the coldest years of the mid-twentieth-century warm period are warmer than the warmest during the earlier cold period (Figs. 12 and 13). This is not the case at Teigarhorn, Grímsey, and Stykkishólmur (Figs. 9, 11, and 12), where the warmest years of the cold period are warmer than the coldest ones of the warm period. In Stykkishólmur the variability of the two periods is not very different, although there is clustering of cold (warm) years during the cold (warm) period (Fig. 11).

The year-to-year persistence in SST is apparently firmer in Vestmannaeyjar and Grindavík (i.e., in the south) than at the other stations (Fig. 13). This is especially evident when one compares the graphs for Papey and Vestmannaeyjar in Figs. 12 and 13. The largest annual change in Vestmannaeyjar (1888-89) is similar to what is "normal" in Papey. The temperature at Vestmannaeyjar rises more or less consistently from 1920 through the 1930s, but the rate of rise is slower after 1929. In Papey the absolute maximum is already reached in 1929, and year-to-year variability is clearly much less during the warm period than the cold one.

The Stykkishólmur SST record is unique because its coldest years occur close to the end of the graph, quite as cold as the cold years in the nineteenth century: this is not so at the other long-term stations (Figs. 9, 12, and 13). Indeed, interannual variability at Stykkishólmur is more evident than decadal variations; an overall trend is not clear and its trace is noisier than the other stations'. This is also counter to the air temperature conditions in Stykkishólmur (Fig. 6 in Hanna et al. 2004). There are at least two possible explanations for this: (i) either the measuring site has changed radically in Stykkishólmur during the time of observations (likely), or (ii) the conditions at the station mainly reflect inner fjord variability where the variance is dominated by strictly local effects such as radiative balance or local runoff, while the air temperature is dominated by largescale advective processes (also likely). Fjord ice may be responsible for the difference between the cold early period and the warm one being smaller than at the other stations. The fjord ice is common during very cold periods so that the temperature of the fjord cannot go further down than to the freezing point of the (diluted) seawater. During cold periods this happens almost every winter while at the other stations this bottom is reached much more infrequently.

\section{Longer-term perspective}

A new paper on the Holocene variation of sea surface and bottom temperatures north and south of Iceland (Smith et al. 2005) puts our paper in a wider perspective and demonstrates the usefulness of our study for similar palaeoclimatic studies in the future. Smith et al. (2005) establish the present-day relationship between $\delta^{18} \mathrm{O}_{\text {carb }}$ and water column temperature using MRI Siglunes section data, then use this relation to help extrapolate palaeotemperatures from $\delta^{18} \mathrm{O}$ in forams along the southwest and north Iceland margins. Smith et al. (2005) found

1) SST variations $\leq 1^{\circ} \mathrm{C}$ for $50 \%$ of observations, with a maximum range $\sim 2.5^{\circ} \mathrm{C}$, over the last $5000 \mathrm{yr}$;

2) a "profound decrease" of $\sim 1.5^{\circ} \mathrm{C}$ in a southwest Iceland fjord SST during the Little Ice Age.

Point 1 suggests a relatively small variation in SST reflecting climatic stability over several thousands of years, while point 2 agrees with the distinct cold depression seen near the beginning of our SST series in the 1880s and 1890s (e.g., Teigarhorn, Grímsey). This is a prime example where improving/extending the published instrumental SST records, for example, our newly derived NIce SST series, can be useful to place results of the current study in a more general climatic context.

\section{Conclusions}

A comprehensive, up-to-date record of available long-term Icelandic SST measurements, which reveals important features of the variability of climate in Iceland and the North Atlantic, has been compiled and presented. We have presented a brief history of the Reykjavík and other significant long-term Icelandic SST measurements, highlighting the main inconsistencies including changes in observing sites. We have extended IMO and DMI source data to include measurements made by the MRI and the harbor authorities. We have used air temperature records and proven statistical procedures to infill many gaps in the SST records. We have spliced together three series to create a new 119 -yr continuous time series for north Iceland SST, which should be generally useful for investigating airsea ice interactions around northern Iceland. As this is the only part of the country to be regularly engulfed by winter and/or spring sea ice, it is therefore incredibly sensitive to climatic change.

The coastal series correlate quite well with HadISST1 series from the adjacent open ocean (mean $r=0.59$ ), although correlations are generally better in summer than winter and in south and east Iceland rather than the west and north. The seasonal temperature range is 
generally twice as large at the coastal sites because of differential effects of radiation, melting, mixing, and advection of warmer or colder air or water masses, as well as spatial resolution differences and smoothing in HadISST1. The coastal SST series reveal long-term variations and trends that are broadly similar to Icelandic air temperature records: that is, generally cold conditions during the late nineteenth and early twentieth centuries; strong warming in the 1920s, with peak SSTs typically being attained around 1940; and cooling thereafter until the 1970s, followed once again by warmingbut not generally back up to the level of the 1930s/1940s warm period.

Our long-term climatological averages and graphs for the 10 SST stations have revealed relatively greater (lesser) long-term variations for the eastern and southern (western and northern) Icelandic coasts. Moreover, Vestmannaeyjar SST data reveal that the late-nineteenthcentury cold period in the ocean was not confined to the cold currents off north and east Iceland but also affected the south coast markedly. The Stykkisholmur SST record is relatively noisy and shows very little decadal variation, which may largely be due to fjord ice in cold winters suppressing low temperatures. In Part II of this study we will present detailed comparative analysis of Icelandic SST and air temperature records, which yields useful insights into air-sea interaction and climatic forcing around Iceland. Our new north Icelandic sea surface temperature (NIce SST) data series can be downloaded from two Web sites (http://www.shef.ac. uk/geography and http://www.vedur.is).

Acknowledgments. We thank the IMO and MRI for Icelandic SST data, the Met Office and British Atmospheric Data Centre for HadISST1 data, Paul Coles for drawing Fig. 1, Dr. Len Wood (University of Plymouth) for the satellite image used in Fig. 2, and David Parker and Nick Rayner (both of Hadley Centre) and Prof. Grant Bigg (University of Sheffield) for advice.

\section{APPENDIX A}

\section{A Translation of the Sea Surface Temperature Measurement Rules of the IMO}

The SST is measured by a special mercury thermometer, usually enclosed in a wooden frame. The measuring site must be chosen for easy access and where the sea is as deep as possible so close to the shore. There must be an open connection to the ocean and small closed inlets and bays should be avoided. One must also avoid proximity to rivers or even small brook outlets.

The sea sample is taken from about $25-50 \mathrm{~cm}$ deep below the surface by using a bucket. The bucket must remain in the sea for some time before it is hauled up. This is to equalize the temperatures of bucket and sea sample. When the bucket has been hauled ashore, full of water, the thermometer is immersed in the water without delay. The water is to be stirred with the instrument until the temperature as read from the thermometer has stabilized. Usually 1 or 2 min of stirring is required, occasionally longer. Neither sunlight nor wind should be allowed to interfere with the measurement as both might influence the seawater temperature. The thermometer must be read with the lower part of the instrument immersed. The reading is to be done by keeping the line from the eye to the top of the mercury column orthogonal to the long axis of the instrument; otherwise, the reading can be wrong. If the sea is covered with ice, a hole needs to be made through the ice and the sea sample hauled up through the hole. This should be noted in the observation journal. If the temperature is negative a minus sign must be used in front of the number read and noted. Sea surface temperature should be measured once per day, after the 9 A.M. general weather observation. In special circumstances (bad weather, ground icing conditions) the measurement can be cancelled. At sites far from the sea the measurement can be made every second day, as authorized by the IMO.

\section{APPENDIX B}

\section{Sea Surface Temperature Measurement Setup at the Automatic Stations of the MRI (Jónsson 1999, Translated from Kristmannsson 1989)}

The measurements were made in harbors, $1-2 \mathrm{~m}$ below spring tide sea level in an exposed position. The temperature was recorded every $2 \mathrm{~h}$ using thermometers of the MS-110SH type produced by Hugrun. The accuracy of the instruments is given by the manufacturer as $\pm 0.1^{\circ} \mathrm{C}$. The thermometers were changed every 3-4 months, which is the normal lifetime of the batteries used. However, there are several gaps in the records causing problems in the analysis. The batteries sometimes failed, resulting in gaps of up to 3 months in some records, and shorter gaps are either due to battery failure or other reasons such as damage to the installation. Daily means of temperature were calculated from the records.

\section{APPENDIX C}

\section{Construction of North Icelandic Sea Surface Temperature Series}

We constructed our new North Icelandic SST series (NIce SST; green line in Fig. 10b) by regressing 12- 
month running means (RMs) of Grímsey SST (Grim12) against 12-month RMs of both Raufarhöfn SST (Rauf12; $r=0.79$ ) and Hraun SST (Hraun12; $r=0.73$ ), using all available data. We calculated new SST values based on these regressions:

$$
\begin{aligned}
& 0.9125 \text { Rauf12 }+0.54444 \text { (July 1922-February 1944) } \\
& 0.9125 \text { Rauf12 }+0.54444 \text { (July 1951-June 1955) } \\
& {[(0.9125 \text { Rauf12 }+0.54444)+(0.8115 \text { Hraun } 12+} \\
& \text { 0.6631) }] / 2 \text { (July 1955-July 2003) }
\end{aligned}
$$

We filled in gaps in the Grim12 rcord, then calculated new 5-yr RMs. NIce SST qualitatively fits the three 5-yr RM series (Grim60, Rauf60, and Hraun60) very well and seems a good continuation of the orginal Grim60 record where there are gaps in the latter.

\section{REFERENCES}

Hanna, E., T. Jónsson, and J. E. Box, 2004: An analysis of Icelandic climate since the nineteenth century. Int. J. Climatol., 24, 1193-1210.

Jónsson, S., 1999: Temperature time series from Icelandic coastal stations. Rit Fiskideildar, 16, 59-68.
Jónsson, T., 2004: Sea surface temperature measurements in the files of the Icelandic Met. Office (in Icelandic). IMO, $13 \mathrm{pp}$.

Kristmannsson, S., 1989: Sjávarhitamælingar við strendur Íslands 1987-1988. Hafrannsóknastofnun Fjölrit No. 17, 102 pp.

Ólafsson, J., 1999: Connections between oceanic conditions off N-Iceland, Lake Myvatn temperature, regional wind direction variability and the North Atlantic Oscillation. Rit Fiskideildar, 16, 41-57.

Rayner, N. A., D. E. Parker, E. B. Horton, C. K. Folland, L. X. Alexander, and D. P. Rowell, 2003: Global analyses of sea surface temperature, sea ice, and night marine air temperature since the late nineteenth century. J. Geophys. Res., 108, 4407, doi:10.1029/2002JD002670.

Smith, L. M., J. T. Andrews, I. S. Castañeda, G. B. Kristjánsdóttir, A. E. Jennings, and A. E. Sveinbjörnsdóttir, 2005: Temperature reconstructions for SW and $\mathrm{N}$ Iceland waters over the last $10 \mathrm{cal} \mathrm{ka}$ based on $\delta 180$ records from planktic and benthic Foraminifera. Quat. Sci. Rev., 24, 1723-1740.

Stefánsson, U., 1954: Temperature variations in the north Icelandic coastal area. Rit Fiskideildar, 2 (2), 1-27.

__, 1962: North Icelandic waters. Rit Fiskideildar, 3, 159-210.

_, and G. Gudmundsson, 1969: Hydrographic conditions off the northeast coast of Iceland in relation to meteorological factors. Tellus, 21, 245-258. 